\title{
Pemberdayaan Tenaga Kerja Indonesia Melalui Koperasi Purna TKW di Kabupaten Malang
}

\author{
Moh Djasuli ${ }^{1}$, Iskandar Zulkarnain ${ }^{2}$, Arie Wahyu Prananta ${ }^{2}$, Merlia Indah ${ }^{2}$ \\ ${ }^{1}$ Fakultas Ekonomi Universitas Trunojoyo Madura \\ ${ }^{2}$ Fakultas IImu Sosial dan IImu Budaya Universitas Trunojoyo Madura \\ Email: mdjasuli@gmail.com
}

Naskah diterima 5 Januari 2018, Revisi 25 Februari 2019, Terbit 20 April 2019

\begin{abstract}
Abstrak
DOI: http://dx.doi.org/10.21107/pmt.v12i1.5178

Wilayah pesisir merupakan wilayah publik yang terbagi menjadi dua, yaitu laut dan darat. Dalam masyarakat pesisir Malang Selatan, kegiatan penangkapan ikan di laut tetap menjadi tanggung jawab laki-laki, sedangkan kaum perempuan terlibat aktif dalam kegiatan perdagangan ikan di darat. Sistem pembagian kerja secara sosial semacam ini merupakan sistem gender yang berlaku pada masyarakat pesisir di Malang Selatan. Karena rendahnya penghasilan nelayan, maka banyak para perempuan di Malang Selatan memilih bekerja ke luar negeri menjadi TKW, namun ternyata menjadi buruh migrant tidak bisa mengangkat status social ekonomi masyarakat di Malang Selatan. Secara akademis, pengabdian ini akan merumuskan karakteristik dinamika pola dan relasi suami-istri keluarga pesisir yang menjadi TKW dalam memerankan wilayah domestik dan publik. Secara sosiologis, kerjasama yang harmonis dan setara akan meningkatkan status sosial keluarga di masyarakat. Karena itu, dalam penelitian ini akan memberikan kontribusi dalam mengurai upaya pemberdayaan perempuan yang menjadi buruh migran melalui penguatan ekonomi tersebut, yaitu merumuskan gender assigment dan gender equality melalui pengelolaan keuangan pola Grameen Bank melalui dana remitan. Peneliti menemukan bahwa di Desa Gedungsalam kecamatan Donomulyo Desa Gedungsalam Malang Selatan beberapa pengelolaan yang dilakukannya awalnya berpola Grameen Bank, namun lambat laun sudah melahirkan UKM-UKM baru, seperti, Warnet, pengetikan computer, pembuatan kripik tempe, dan lain sebagainya.
\end{abstract}

Kata kunci : tenaga kerja wanita, pemberdayaan perempuan, grameen bank

\section{PENDAHULUAN}

Kemiskinan dan keterbelakangan masyarakat pesisir terutama komunitas nelayan merupakan hal lama yang tak dapat dielakkan, rintihan pilu masyarakat pesisir tidak jua kunjung reda. Semestinya bangsa Indonesia bangga memiliki masyarakat yang rela bekerja dengan semangat luar biasa bahkan mencurahkan hidup dan matinya untuk mengelola sumber daya kemaritiman yang dimiliki Indonesia. Mengingat pembangunan kemaritiman bagi bangsa ini merupakan modal besar dan peluang lebar untuk menuju persaingan ekonomi global. Dengan memberdayakan masyarakat pesisir dari kemiskinan dan keterbelakangan adalah langkah yang sangat mendasar dalam tahap awal pembangunan kemaritiman.
Berbagai hasil kajian, selama ini, tentang kehidupan sosial ekonomi masyarakat telah mengungkapkan bahwa sebagian besar dari mereka, khususnya yang tergolong nelayan buruh atau nelayan-nelayan kecil, hidup dalam kubangan kemiskinan. Kemampuan mereka untuk memenuhi kebutuhan dasar minimal kehidupan sehari-hari sangat terbatas. Bagi masyarakat nelayan, di antara beberapa jenis kebutuhan pokok kehidupan, kebutuhan yang paling penting adalah pangan. Adanya jaminan pemenuhan kebutuhan pangan setiap hari sangat berperan besar untuk menjaga kelangsungan hidup mereka (Kusnadi, 2006)

Wanita nelayan adalah suatu istilah untuk wanita yang hidup di lingkungan keluarga nelayan, baik sebagai istri maupun anak dari nelayan pria. Kaum 
wanita di keluarga nelayan umumnya terlibat dalam aktivitas mencari nafkah untuk keluarganya. Selama ini wanita nelayan bekerja menjadi pengumpul kerang-kerangan, pengolah hasil ikan, pembersih perahu yang baru mendarat, pengumpul nener, membuat/memperbaiki jaring, pedagang ikan dan membuka warung (Kusnadi, 2006).

Namun, pada kenyataannya langkah tersebut belum menunjukkan sinyal yang pasti. Kurangnya akses pendidikan dan kesehatan bagi masyarakat pesisir adalah suatu pertanda bahwa nasib mereka masih berada dalam ketidakjelasan, sehingga akibatnya sumber daya masyarakat (SDM) yang mereka miliki sangat minim dalam mengelola kekayaan laut yang melimpah. Bukannya mereka tidak memiliki usaha yang keras dan keinginan yang gigih dalam memajukan sosial-ekonominya. Tapi, karena keterbatasan pendidikan, informasi dan teknologi yang membuat mereka harus menerima apa adanya.

Berawal dari itulah, maka banyak para perempuan masyarakat di daerah pesisir, terutama di Kecamatan Donomulyo Desa Kedungsalam Kabupaten Malang, memilih untuk menjadi buruh migrant, terutama di Hongkong, dengan alasan utamanya untuk meningkatkan status social ekonomi keluarganya. Pada perkembangannya menjadi buruh migrant tidak menyebabkan peningkatan status social ekonomi para TKW di sana. Sehingga para TKW membuat inisiatif untuk membuat kumpulan di Hongkong sebagai embrio lahirnya koperasi wanita purna TKW yang berbasis dana remitan mereka.

Pengelolaan koperasi purna TKW 'Bina Mandiri' melalui dana remitan ini, kemudian oleh kami (pengabdi) polakan menjadi koperasi berpola Grameen Bank. Grameen Bank adalah sebuah organisasi kredit mikro yang dimulai di Bangladesh yang memberikan pinjaman kecil kepada orang yang kurang mampu tanpa membutuhkan collateral. Sistem ini berdasarkan ide bahwa orang miskin memiliki kemampuan yang kurang digunakan. Yang berbeda dari kredit ini adalah pinjaman diberikan kepada kelompok perempuan produktif yang masih berada dalam status sosial miskin.
Pola Grameen Bank ini telah diadopsi oleh hamper 130 negara di dunia, kebanyakan di negara Asia dan Afrika, termasuk Indonesia. Jika diterapkan dengan konsisten, pola Grameen Bank ini dapat mencapai tujuan untuk membantu perekonomian masyarakat miskin melalui perempuan.

Keterlibatan perempuan pada wilayah publik dalam keluarga pesisir untuk menjadi buruh migran tidak hanya bermanfaat bagi kelangsungan hidup rumah tangga, peningkatan kapasitas diri, dan status sosial dalam struktur sosial masyarakatnya, tetapi memberi kontribusi terhadap dinamika sosial-ekonomi masyarakat lokal. Karena itu, kaum perempuan (istri) tidak hanya menjadi potensi sosial budaya, akan tetapi juga sangat potensial dalam pengembangan ekonomi dan pendidikan juga.

Secara psikologis dinamika peran ini akan memberikan kepercayaan diri, motivasi serta penghargaan dan harga diri perempuan yang relatif sama dengan lakilaki. Kapasitas dan kapabilitas perempuan tidak menjadi nomor dua seperti yang selama ini dimaknai dalam ranah sosiologis-kultural maupun fenomena teologis dengan pemaknaan ayat-ayat alQur'an yang reduktif dan distortif.

\section{METODOLOGI}

Sasaran dari penelitian ini dipilih menjadi dua bagian yaitu: (1) Sasaran primer dari kegiatan program ini adalah anggota TKW yang ada di Malang Selatan terutama anggota koperasi purna TKW 'Bina Mandiri', (2) Sasaran antara atau sekunder dalam kegiatan ini adalah warga masyarakat lain yang belum mendapatkan pelatihan pemberdayaan masyarakaat pesisir dan mereka berharap mengikuti pelatihan dan pemberdayaan dalam mengoptimalkan potensi masyarakat pesisir terutama keluarga TKW dalam mengelola dana remitan

Keterkaitan antara program penelitian dengan mitra adalah adanya hubungan timbal balik yang saling menguntungkan. Bagi tim peneliti, kegiatan ini dilakukan untuk mengidentifikasi permasalahan para keluarga TKI dalam upaya pengentasan kemiskinan dan menaganalisis kebutuhan masyarakat TKI dalam meningkatkan 
kapasitas dalam ekonomi dan pendidikan. Bagi Masyarakat Mitra dapat memperolah manfaat untuk meningkatkan pengetahuan dan peluang usaha berdasar temuan pengabdian yang telah dilakukan oleh perguruan tinggi mitra.

Metode yang dilakukan dalam pelaksanaan program ini adalah :

1. Metode Wawancara mendalam (indeptinterview). Wawancara mendalam dilakukan responden kunci menjadi sasaran program, terutama dari kalangan perempuan pesisir purna TKW yang menjadi pengurus inti koperasi 'Bina Mandiri'.

2. Memberikan pelatihan dan proses hingga tercipta peluang usaha entrepreneurship bagi UKM melalui perbaikan manajemen pengelolaan koperasi melalui dana remitan berpola Grameen Bank.

3. Membentuk kelompok masyarakat pesisir yang cinta kepada pendidikan.

\section{HASIL DAN PEMBAHASAN}

Penggunaan remitan tidak diatur sama sekali dalam peraturan perundangundangan yang mengatur masalah migran, karena hal itu dianggap sebagai wilayah pribadi, tapi dalam peraturan perundang-undangan yang lain, misalnya pembagian harta ketika perceraian terjadi atau peraturan mengenai waris tentu saja digunakan. Demikian pula mores maupun folkways yang berkembang di daerah tersebut (Hilmy, 2008).

Remitan merupakan salah satu hal penting yang tidak dapat dipisahkan dalam seluruh proses migrasi. Remitan merupakan produk yang dihasilkan oleh migran yang merupakan reward yang sangat dinantikan dan diharapkan oleh keluarga migran di daerah asal. Akan tetapi, sesungguhnya remitan tidak hanya dinanti oleh keluarga migran tetapi secara tidak langsung hasil migran ini bermanfaat juga untuk daerah asal dan bahkan negara Indonesia. Dengan demikian, remitan dapat diartikan sebagai sesuatu yang dihasilkan dari suatu proses migrasi yang dikirim ke daerah asal baik dalam bentuk materil seperti barang maupun uang maupun dalam bentuk yang immateril seperti peningkatan kualitas ketrampilan dan ide-ide pembangunan yang bermanfaat bagi daerah asal migran.

Menelusuri konteks-konteks kekuatan pola ketidakadilan terhadap TKW, maka akan juga terlihat bagaimana inisiatif perempuan serta strategi untuk mewujudkannya. Beberapa perempuan menyadari bahwa kekuataan-kekuatan pola ketidakadilan bisa menutup akses mereka untuk mewujudkan inisiatifnya.

Lastri, salah satu informan menyebutkan bahwa bisa bekerja di Hongkong maka dia harus mengahadapi suami dan nilai-nilai budaya masyarakat setempat. Dia menyadari adanya nilai-nilai sosial yang menyebutkan bahwa sudah seharusnya istri berada di samping suaminya dan mengurus pekerjaan domestik serta menjaga anak-anaknya. Meskipun pada awalnya dilarang oleh orang tua dan suami untuk bekerja di Hongkong, tetapi Lastri selalu mendesak. Dia bahkan menggunakan alasan untuk merubah perekonomian keluarga menjadi argumentasi utamanya agar orang tua dan suaminya memberikan ijin. Strategi ini ternyata berhasil. Hal yang sama juga dilakukan oleh beberapa TKW lainnya. Alasan ekonomi menjadi dalih yang sudah populer di kalangan TKW agar bisa mewujudkan keinginannnya bekerja di Luar negeri. Beberapa informan mengaku belajar dari pengalaman mantan TKW lainnya perihal penggunaan alasan ekonomi sebagai strategi mewujudkan insiatifnya (Hilmy, 2008).

Juwariyah, sekembalinya dari bekerja di Hongkong, bahkan sudah mulai berani mengungkapkan usulannya terkait dengan kepentingan keluarga seperti membangun rumah dan mengatur pola asuh anak. Juwariyah mengaku jika bermusyawarah tentang hal ini bersama orang tua dan suaminya, dia sudah mulai bisa mendominasi pembicaraan. Bahkan dia sudah bisa meyakinkan suaminya bahwa pendapatnya benar. Bagi Juwariyah mengungkapkan hal-hal yang sifatnya rasional dan bisa diterima oleh suami, ketimbang berpegang pada nilai-nilai irasional, adalah strategi agar dia bisa mengambil keputusan pada ranah-ranah tertentu di lingkungan keluarga.

Beberapa TKW lain juga memiliki pengalaman yang hampir sama dengan 
Juwariyah. Ernawati, mantan TKW bahkan sudah mempunyai kuasa untuk mengolah sendiri uang hasil jerih payah bekerja selama di Hongkong. Dalam kehidupan rumah tangga, Ernawati juga dipercayakan oleh suaminya untuk mengambil keputusan dalam hal pengasuhan anak. Mantan TKW memang mengambil strategi dengan cara menciptakan pola-pola pengambilan keputusan bersama dalam rumah tangga. TKW yang sudah menikah biasanya berkompromi dengan suami untuk berbagi peran dalam pengambilan keputusan. Meskipun demikian, posisi perempuan masih lebih banyak memegang pengambilan keputusan untuk hal-hal yang sifatnya masih domestifikasi, seperti pengasuhan anak, pembelian keperluan bahan rumah tangga, menata rumah, dan sebagainya.

Hal menarik dialami oleh Maisiah, Maisiah adalah seorang perempuan yang menjadi korban selingkuh suami saat dia tinggalkan bekerja selama beberapa tahun. Dalam menghadapi relasi dalam pernikahan, di mana suami mempunyai kekuatan untuk melakukan hubungan seksual selain dengan istri, Maisiah berani menggugat cerai suaminya. Menurut Maisiah, hal tersebut dilakukan agar dia tidak ditindas dan disakiti oleh suaminya. Maisiah mengungkapkan bahwa dengan bercerai, maka suaminya tidak akan bisa menyakiti, menindas dan merampas hakhaknya. Tindakan perceraian yang dilakukan Maisiah membawa hasil. Saat ini Maisiah mengaku bahwa mereka telah rujuk, dan dia memiliki keuatan setara dengan suaminya. Saat ini, suami Maisiah sangat menghormati hak-haknya, terutama haknya sebagai istri.

TKW memang mempunyai inisiatifinisiatif agar mereka bisa memperoleh, mengakses dan mengontrol hak-haknya. Bekerja ke luar negeri merupakan inisiatif perempuan di desa Kedungsalam, meskipun beberapa perempuan memang mengungkapkan bahwa inisiatif ini muncul setelah melihat kesuksesan kerabat, tetangga atau teman yang sudah terlebih dahulu pergi menjadi TKW.

TKW asal desa Kedungsalam yang bekerja di Hong Kong memang mau tidak mau harus berhadapan dengan pemotongan gaji. Akibat pemotongan gaji ini adalah tidak diterimanya sejumlah uang upah pekerjaan mereka. Belum ada perlawanan yang berarti yang dilakukan oleh kebanyakan perempuan di desa Kedungsalam perihal ini. Hampir semua mantan TKW yang menjadi informan, menganggap bahwa pemotongan gaji masih dianggap sebagai sebuah kewajiban pembayaran sebagai konsekuensi pembiayaan pemberangkatan mereka dari desa ke Hongkong.

Inisiatif yang terlihat atas keadaan ini justru membuat beberapa TKW melakukan kerja lembur atau bekerja di dua majikan guna tetap memperoleh upah yang sangat di bawah standar. Hal ini dilakukan Yunestutik yang menguraikan bahwa dirinya bekerja pada dua majikan, yaitu majikan sesuai kontrak kerja dan majikan lain yang merupakan saudara majikan aslinya. Dengan majikan asli Yunestutik melakukan kerja full time, sementara dengan majikan lain dia bekerja part time. Bagi Yunestutik ini adalah strategi supaya dia tetap bisa memperoleh penghasilan atau uang yang merupakan haknya. Beberapa TKW lain bahkan melakukan strategi kerja lembur di hari libur untuk tetap memperoleh penghasilan. Sebuah ironi, bahwa beberapa TKW, tanpa disadarinya, melakukan tindakan yang sama saja dengan mengeksploitasi diri guna memperoleh penghasilan.

Beberapa TKW yang memiliki hari libur mengungkapkan biasanya mereka menghabiskan waktu liburan mereka di sebuah taman bernama Victoria Park. Pada kesempatan ini mereka bertemu dengan sesama pekerja dari Indonesia, bercerita dan saling bertukar informasi. Juwariyah adalah salah seorang mantan TKW yang pernah berinisiatif mengumpulkan teman-temannya dalam sebuah wadah kegiatan pengajian atau 'tahlil'. Juwariyah bercerita bahwa pada saat di Hongkong dia berhasil mengumpulkan 50 orang sesama TKW yang berasal dari Desa Kedungsalam untuk mengadakan 'tahlil' atau kumpulan setiap minggunya di taman Victoria Park. Pada awalnya pembentukan kelompok tahlil ini ditujukan untuk menggalang 
solidaritas sesama buruh migran asal desanya.

Pada awalnya, 'tahlil' memang dilakukan untuk mendoakan seorang anggota keluarga TKW yang meninggal. Kegiatan ini menjadi kegiatan rutin setelah banyak TKW lain yang ikut. Dalam perkembangannya, kelompok 'tahlil' ini tidak hanya melakukan doa-doa semata. Lebih dari itu, mereka mulai melakukan kegiatan menabung (penyimpanan uang) dan ruang untuk saling berkomunikasi. Menurut penuturan Juwariyah, sampai dengan saat ini, meskipun dirinya sudah berada di Indonesia, kelompok tersebut masih terbentuk.

Menurut penuturan mantan TKW, berkomunikasi dengan sesama TKW di saat hari libur merupakan strategi mereka untuk keluar dari tekanan rutinitas pekerjaan. Mulai hari Senin sampai dengan Sabtu biasanya TKW disibukkan oleh jadwal pekerjaan rumah tangga yang ketat. Tidak ada waktu istirahat, apalagi bagi mereka yang bekerja mulai pagi sampai larut malam.

Keberadaan Victoria Park menjadi ruang mereka untuk mengeluhkan kelelahan dengan sesama rekan TKW, bersenang-senang bersama dengan sesama teman dari Indonesia secara umum, dan dari desa Kedungsalam secara khsusu, memasak bersama makanan khas Indonesia, dan memunculkan perasaan kolektif senasib dan sepenanggungan. Beberapa mantan TKW bahkan mengungkapkan hari libur di Victoria Park menjadi ajang yang selalu dinanti-nanti. Tidak jarang ada yang memanfaatkan hari libur ini untuk menjalin hubungan dengan pacar atau kekasihnya (Hilmy, 2008).

Beberapa mantan TKW yang menjadi informan juga mengungkapkan bahwa pada saat hari libur tersebut, akan dapat dilihat kelompok-kelompok TKW Indonesia. Kelompok-kelompok ini berkumpul tergantung kepentingannya. Bagi TKW yang menjadi informan, berkumpul di hari minggu adalah strategi untuk refreshing dari kesibukan, strategi menghilangkan kepenatan dengan majikan, strategi untuk bisa bergaul dengan banyak orang, strategi untuk bisa berkomunikasi dan saling tukar informasi, dan sebagainya (Hilmy, 2008).

Saat kembali ke kampung halaman ke desa Kedungsalam, TKW kembali harus menghadapi situasi sosial budaya masyarakat desa yang jauh berbeda dengan masyarakat kota besar seperti Hongkong. Salah satu hak TKW yang perlu mendapatkan perhatian adalah akses dan kontrol atas pengelolaan penghasilannnya (remitan).

Saat kembali berada di desa Juwariyah mempunyai inisiatif untuk mengatasnamakan semua hasil yang diperoleh melalui bekerja di Hongkong dengan namanya. Sertifikat atas tanah yang dia beli menggunakan uang pribadinya, diatasnamakan nama Juwariyah. Begitu pula dengan barang furniture yang ada di dalam rumahnya dibeli Juwariyah menggunakan uang gajinya. Rumah yang saat ini ditinggali juga merupakan hasil jerih payah Juwariyah.

Selain pengalaman Juwariyah, juga ada pengalaman Ernawati. Ernawati saat ini memiliki 2 sertifikat tanah. Atas inisiatifnya sendiri, kedua nama dalam sertifikat itu adalah atas nama dirinya. Inisiatif ini membuat sertifikat tanah atas namanya merupakan strategi yang dilakukan Ernawati agar hak kepemilikan harta hasilnya bekerja di Hongkonng tidak jatuh ke tangan suami. Pengalaman dikhianati suami berselingkuh saat ia masih di Hong Kong membuatnya tergerak untuk mengamankan hasil jerih payah bekerjanya di Hongkong.

Strategi membuat sertifikat atas namanya dilakukan agar dia tidak dipermainkan oleh laki-laki atau dieksploitasi oleh laki-laki. Strategi ini dilakukan secara sadar oleh Ernawati. Meskipun suaminya masih dianggap berperan sebagai kepala keluarga, Ernawati tidak tinggal diam untuk pengelolaan penghasilannya.

Strategi perempuan

Kedungsalam menghadapi kekuatan perilaku ketidakadilan terhadap para TKW agar dapat mewujudkan insiaitif kebanyakan bersumber dari dalam diri individu mereka (mantan TKW). Artinya, perempuan harus berhadapan dengan struktur kelas. Selain itu juga ada nilai 
budaya, kondisi ekonomi, stereotipe, dan sebagainya.

Mantan TKW desa Kedungsalam harus berhadapan dengan kenyataan adanya struktur kelas yang menutup akses dan kontrol mereka atas hak-haknya. Struktur kelas juga merekat dengan adanya nilai budaya berupa adat istiadat, norma sosial, sangsi sosial, stereotipe, pemiskinan, dan sebagainya. Fenomena ini terjadi di setiap proses migrasi yang dilalui TKW asal desa Kedungsalam (Hilmy, 2008).

Berdasarkan observasi dan interview dengan sejumlah informan mantan TKW di desa Kedungsalam, terlihat bahwa para mantan TKW di Desa ini memang sudah memiliki kesadaran untuk berkumpul bersama, membentuk suatu kelompok maupun organisasi guna menuntut perolehan atas hak-hak mereka, meskipun awalnya berasal dari kumpulan tahlilan para ibu-ibu. Namun para mantan TKW menyadari tentang hak dan kebutuhan mereka sebagai perempuan dan warga masyarakat. Keinginan untuk berkumpul memang sudah mulai ada sejak beberapa tahun terakhir. Kelompok ini didasarkan pada kebutuhan perempuan-perempuan yang ada di desa.

Pernyataan serupa disebutkan oleh Siti, seorang tokoh agama perempuan. Dia mengungkapkan bahwa kelompok tahlil di desa Kedungsalam dibuat sejak tahun 2002. Saat itu, Siti bercerita, dirinya diminta untuk memimpin tahlil tersebut. Secara bersama-sama perempuan memilih ibu Siti untuk menjadi pimpinan tahlil ini. Alasannya karena ibu Siti memiliki pengetahuan agama Islam yang lumayan baik (Hilmy, 2008).

Kegiatan dalam kelompok tahlil juga semakin berkembang. Kegiatan ini tidak lagi hanya sebatas pada kegiatan pengajian dan pemahaman ajaran agama Islam atau mendoakan arwah-arwah keluarga yang sudah meninggal. Dalam kelompok tahlil juga sudah mulai dilakukan arisan, yang menurut perempuan di desa Kedungsalam merupakan bagian dari sarana belajar menabung. Mantan TKW juga bertutur bahwa kelompok tahlil di desanya sudah menjadi sarana saling bertukar informasi tentang berbagai hal.
Tokoh agama Islam di desa Kedungsalam memang memiliki minat besar untuk mengembangkan kelompokkelompok perempuan. Kegiatannya berisikan nilai-nilai keagamaan. Namun, untuk mengorganisir sebuah kelompok perempuan di desa Kedungsalam memang tidak mudah. Hal inilah yang menjadi penggerak dari agent of change tersebut untuk memanfaatkan arisan tahlil bukan hanya sekedar rutinitas pengajian. Namun, bisa lebih bermanfaat untuk menciptakan pola pengelolaan hasil dari upah yang mereka dapat sebagai TKW di Hongkong. Mulai tahun 2009 rencana tersebut disepakati oleh semua anggota arisan tahlil untuk membuat koperasi perempuan dengan nama "Bina Mandiri", sebagai upaya pengelolaan dana remitan dari para mantan TKW desa Kedungsalam, yang diketuai oleh Latiyah, dengan jumlah anggota 22 orang.

Menurut Dinas Koperasi ada beberapa syarat yang harus dimiliki oleh sekelompok orang untuk mendirikan koperasi. Ada persyaratan umum dan ada juga persyaratan khusus tentang bentuk koperasi tersebut seperti apa, apakah koperasi simpan pinjam, unit jasa keuangan syari'ah, unit simpan pinjam, dan koperasi jasa keuangan syariah (Kementrian Koperasi dan UKM RI, 2011).

Secara umum dasar hukum pembentukan koperasi, adalah Undangundang No. 25 tahun 1992 tentang perkoperasian; PP No. 4 tahun 1994 tentang persyaratan dan tata cara pengesahan akta pendirian dan perubahan anggaran dasar koperasi; dan peraturan menteri No. 01 tahun 2006 yaitu tentang petunjuk pelaksanaan pembentukan, pengesahan akta pendirian dan perubahan anggaran dasar koperasi. Lebih lanjut, koperasi sebaiknya dibentuk oleh sekelompok orang/anggota masyarakat yang memiliki kegiatan dan kepentingan ekonomi yang sama; sebelum mendirikan koperasi, sebaiknya didahului dengan penyuluhan tentang perkoperasian agar kelompok masyarakat yang ingin mendirikan koperasi tersebut memahami mengenai perkoperasian, sehingga anggota koperasi nantinya benar-benar memahami nilai dan prinsip koperasi dan paham akan hak dan 
kewajibannya sebagai anggota koperasi (Pasal 3 dan Pasal 4).

Sedangkan proses pendirian koperasi dimulai dengan pelaksanaan rapat pembentukan koperasi di mana untuk koperasi primer sekurang-kurangnya dihadiri oleh 20 orang anggota pendiri, sedangkan untuk koperasi sekunder sekurang-kurangnya dihadiri oleh 3 koperasi melalui wakil-wakilnya (Pasal 5 Ayat 1); dan rapat pembentukan koperasi tersebut dihadiri oleh pejabat dinas/instansi/badan yang membidangi koperasi setempat sesuai dengan domisili anggota (Pasal 5 Ayat 3), di mana kehadiran pejabat tersebut bertujuan antara lain: (a) memberikan arahan berkenaan dengan pembentukan koperasi, (b) melihat proses pelaksanaan rapat pembentukan, (c) sebagai narasumber apabila ada pertanyaan berkaitan dengan perkoperasian dan (d) untuk meneliti isi konsep anggaran dasar yang dibuat oleh para pendiri sebelum di 'akta' kan oleh Notaris Pembuat Akta Koperasi Setempat. Selain itu, apabila memungkinkan rapat pembentukan tersebut juga dapat dihadiri oleh Notaris Pembuat Akta Koperasi yaitu Notaris yang ditetapkan melalui Keputusan Menteri Negara Koperasi dan UKM untuk membantu membuat/menyusun akta pendirian, perubahan anggaran dasar, dan pembubaran koperasi.

Dalam rapat tersebut akan dibahas beberapa persoalan, yaitu: (1) nama dan tempat kedudukan, (2) maksud dan tujuan, (3) jenis koperasi dan bidang usaha, (4) keanggotaan, (5) rapat anggota, (6) pengurus, pengawas, dan pengelola, serta (7) permodalan, jangka waktu dan sisa hasil usaha. Sedangkan pembuatan atau penyusunan akta pendirian koperasi tersebut dapat dibuat oleh para pendiri (dalam hal di wilayah setempat tidak terdapat NPAK) atau dibuat oleh Notaris Pembuat Akta Koperasi (Pasal 6 Ayat 1). Selanjutnya, Notaris atau kuasa pendiri mengajukan permohonan pengesahan secara tertulis kepada pejabat yang berwenang dengan dilampirkan (Pasal 7 Ayat 1): (a) dua rangkap salinan akta pendirian bermaterai cukup, (b) data akta pendirian koperasi yang dibuat dan ditandatangani Notaris, (c) surat bukti tersedianya modal yang jumlahnya sekurang-kurangnya sebesar simpanan pokok dan simpanan wajib yang wajib dilunasi oleh para pendiri, (d) rencana kegiatan usaha minimal tiga tahun ke depan dan RAPB, dan (e) dokumen lain yang diperlukan sesuai peraturan perundang-undangan.

Setelah semuanya tercukupi maka Pejabat yang berwenang akan melakukan; penelitian terhadap materi anggaran dasar yang diajukan (Pasal 8 Ayat 2) dan pengecekan terhadap keberadaan koperasi tersebut (Pasal 8 Ayat 2). Apabila permohonan diterima maka pengesahan selambat-lambatnya tiga bulan sejak berkas diterima lengkap (Pasal 9 Ayat 2). Jika permohonan ditolak maka keputusan penolakan dan alasannya disampaikan kembali kepada kuasa pendiri paling lama tiga bulan sejak permohonan diajukan (Pasal 12 Ayat 1). Terhadap penolakan tersebut, para pendiri dapat mengajukan permintaan ulang pengesahan akta pendirian koperasi dalam jangka waktu paling lama satu bulan. Keputusan terhadap permintaan ulang tersebut diberikan paling lambat satu bulan (Pasal 12 Ayat 2).

Berawal dari proses perkumpulan tahlilan inilah para ibu-ibu dan mantan TKW berupaya untuk membuat koperasi. Proses pendirian koperasi sebenarnya dimulai sejak lama sejak tahun 2002, namun baru 2009 perkumpulan tahlilan ini betul-betul memproses penciptaan koperasi dengan nama 'Bina Mandiri, dengan ketuanya Latiyah dan diikuti oleh 22 orang, dengan alamat Jl. Raya Pantai Ngliyep Rt 20 Rw 4 Desa Kedungsalam Kecamatan Donomulyo Kabupaten Malang, dengan Notarisnya Itta Andrijani, $\mathrm{SH}$, dan baru pada tanggal 30 Maret 2010 koperasi 'Bina Mandiri' ini mendapatkan akta pendirian dari Dinas Koperasi dan UKM Kabupaten Malang dengan Nomor 183/BH/XVI.14/III/2010, dengan bentuk koperasi perempuan simpan pinjam (KSP).

Saat ini koperasi 'Bina Mandiri' sudah memiliki 47 anggota dengan simpanan pokok sebesar Rp 50.000-. dan simpanan wajib minimal sebesar Rp 10.000-./bulan. Dari sinilah kemudian koperasi itu berkembang dan memiliki berbagai bentuk 
usaha lain, di antaranya adalah usaha kripik pisang, kripik emping, dan penanaman pohon sengon, serta rental pengetikan computer, dan warnet, dengan bantuan dari Windows pada tahun 2011.

Setiap anggota diperbolehkan untuk meminjam dana koperasi sebesar $\mathrm{Rp}$ 1.000.000 - 2.000.000-. per anggota, dengan alas an untuk kebutuhan usaha keluarga dan kepentingan keluarga. Dari peminjaman ini setiap anggota diwajibkan untuk membayar per minggu sebesar kemampuan mereka. Dan dari hasil pembayaran ini koperasi mendapatkan keuntungan seikhlasnya para anggota yang meminjamnya. Bahkan pola seperti ini lebih baik dan berkeadilan ketimbang pola Grameen Bank di mana polanya adalah bank ini dimiliki oleh peminjam miskin dari bank Grameen Bank tersebut, yang kebanyakan adalah perempuan. Dan sekitar $94 \%$ dimiliki oleh peminjam, dan sisa $6 \%$ dimiliki oleh Pemerintahan Bangladesh. Bahkan setiap akhir tahunnya para anggota koperasi 'Bina Mandiri' bisa mendapatkan Sisa Hasil Usaha (SHU) sebesar Rp 150.000-. secara merata, dengan tidak melihat struktur kepengurusan keanggotaannya. Dalm artian baik yang duduk sebagai pimpinan ataupun bawahan mendapatkan SHU yang sama.

Pola ini sesuai dengan bentuk Grameen Bank, yaitu metode yang digunakan Grameen Bank ini berupa group lending, group sanction atau collateral. Berbeda dengan sistem dan prinsip bank konvensional, cara kerja Grameen Bank melalui pemberian kredit kepada orang miskin, yang sebagian besar tidak berpenghasilan tetap. Grameen Bank merancang kredit mikro berbasis kepercayaan bukan kontrak legal. Konkretnya, peminjam diminta membuat kelompok yang terdiri dari lima orang dengan satu pemimpin. Pinjaman diberikan secara berurutan dengan catatan orang kedua baru bisa meminjam setelah pinjaman orang pertama dikembalikan. Pembayaran pinjaman yang dilakukan Grameen Bank diberikan kepada suatu kelompok miskin, dan pembayarannya juga melalui kelompok itu. Jika terdapat nasabah yang tidak mampu membayar, maka teman dalam satu kelompoknya harus membantu supaya orang tersebut mampu membayar. Selain itu, kelompok peminjam dituntut membuat pelbagai agenda sosial yang bermanfaat bagi masyarakat di sekitarnya. Ada kombinasi antara modal uang dan modal sosial. Dengan menerapkan modal sosial ini, pengembalian utang kepada Grameen Bank bisa mencapai 99\%.

Demi keberlanjutan antargenerasi, Grameen Bank memfokuskan pinjaman pada perempuan. Ada dua misi dari aksi ini: Pertama, pemberdayaan perempuan dengan meningkatkan posisi tawar mereka, baik di ruang privat maupun publik. Kedua, peningkatan kualitas hidup anak. Riset membuktikan, peningkatan ekonomi perempuan berbanding lurus dengan tingkat pendidikan dan kesehatan anak. Pemberdayaan ekonomi perempuan berhubungan langsung dengan turunnya angka kematian bayi dan malnutrisi (Kuncoro, 2008).

Hal inilah yang dilakukan oleh para anggota koperasi 'Bina Mandiri' terutama para mantan TKW, di mana penghasilan yang mereka dapatkan dari Hongkong sudah habis, karena dibelikan tanah, perbaikan rumah, kendaraan, dan usaha lainnya. Sehingga hasil dari pembelanjaan tersebut, seperti tanahnya ditanami pisang, pohon sengon, ketela, dan lainnya, maka keuntungan yang didapatnya biasanya untuk menutupi kebutuhan sehari-hari mereka dan sisanya untuk ditabungkan ke koperasi 'Bina Mandiri' atau untuk membayar hutang kepada koperasi 'Bina Mandiri'.

Sehingga sampai saat ini hampir mayoritas mantan TKW yang berasal dari Desa Kedungsalam sesudah purna jadi TKW bisa dikategorikan sebagai mantan TKW yang mampu mengangkat derajat social ekonomi keluarganya. Bahkan mereka sudah bisa memperbaiki kondisi ekonomi desanya melalui sumbangan wajib yang diminta oleh aparat desa. Kemapanan ekonomi dan kemandirian mantan TKW ini yang semakin memperkuat basis kesadaran masyarakat Desa Kedungsalam Donomulyo untuk lebih menghargai arti pentingnya ilmu pendidikan melalui pendidikan formal. Sehingga saat ini sangat jarang anak muda Desa Kedungsalam sekolahnya 
hanya sampai tingkat SLTP. Pola keuntungan dan resiko yang seimbang dalam pola simpan pinjam inilah landasan utama dari lahirnya koperasi 'Bina Mandiri', yang dilandasi dengan rasa kebersamaan dan kepercayaan terhadap masing-masing pengurus dan anggota dari koperasi tersebut. Rasa kebersamaan akibat perilaku ketidakadilan yang dialami mereka ketika menjadi TKW dan kemiskinan serta lemahnya pendidikan menjadi fondasi kekuatan yang luar biasa dalam proses pembentukan, pelaksanaan, dan memajukan koperasi 'Bina Mandiri' ini.

Proses pengelolaan dana remitan untuk dipolakan dengan system Grameen Bank sebagaimana di koperasi 'Bina Mandiri' memang masih proses panjang, di mana Grameen Bank sebenarnya bisa dikategorikan sebagai pola pengembangan sistem perbankan yang mungkin dapat disebut sebagai sistem perbankan kerakyatan, di antaranya adalah model Grameen Bank yang ada di Bangladesh. Sebagaimana dikemukakan oleh Manurung (1998), sebagai pengganti kelangkaan agunan yang dialami usahausaha ekonomi rakyat, alternatif yang ditawarkan oleh Grameen Bank adalah dengan mengorganisasikan para calon debiturnya melalui pembentukan kelompok atau pusat. Selain berfungsi sebagai pengganti agunan, pengorganisasian para debitur Grameen Bank juga dimaksudkan untuk : (1) menumbuhkan rasa aman dan rasa percaya diri dalam melakukan prakarsa baru; (2) sebagai wahana utama bagi partisipasi para anggotanya dalam kegiatan proyek; (3) sebagai sumber tekanan terhadap anggotanya agar memenuhi kewajibannya terhadap bank, dan untuk mendorong mereka agar memiliki keberanian dalam meninggalkan sikap-sikap tradisional yang tidak diperlukan, serta untuk mencegah perbuatan anti sosial; (4) melalui pembentukan kelompok, terbuka peluang bagi mereka yang lemah untuk mengubah keadaan mereka menjadi kekuatan kolektif. Sebagai kelengkapan dari pengembangan modal institusional tersebut, Grameen Bank juga menerapkan apa yang disebut sebagai ikrar 16 pasal, yaitu yang ditujukan untuk meningkatkan disiplin, persatuan, kerja keras, kesejahteraan setiap anggota kelompok debitur. Ikrar terhadap 16 pasal itu wajib dilakukan setiap pertemuan pusat (meliputi 5-6 kelompok) yang dilakukan setiap minggu. Bahkan, terkait dengan pengembangan modal intelektual, setiap pusat juga dianjurkan mendirikan sekolah. Model lain yang juga dapat sebagai pengejewantahan sistem perbankan kerakyatan adalah sistem perbankan bagi hasil (Bank Islam).

Prinsip utama sistem perbankan bagi hasil adalah pembagian keuntungan dan resiko secara berkeadailan antara debitur, kreditur dan penabung. Dengan adanya pembagian keuntungan dan resiko yang seimbang tersebut diharapkan muncul rasa tanggungjawab bersama dalam penyaluran kredit dan pengelolaan proyek (Yunus, 2003).

Lembaga perbankan menjadi salah satu sumber modal, secara optimal masih belum membantu permasalahan yang dihadapi usaha kecil menengah. Relatif tingginya tingkat bunga kredit perbankan, prosedur serta persyaratan pengajuan kredit yang relative sulit untuk dipenuhi, serta tidak adanya jaminan merupakan alasan utama bagi sebagian besar Usaha Mikro Kecil Menengah untuk tidak mengajukan kredit kepada perbankan, untuk usaha kecil menengah dengan segala keterbatasannya masih sulit untuk meraih modal dari sumber-sumber modal dan lembaga-lembaga keuangan nonbank

Berawal dari berbagai persoalan tersebut maka koperasi wanita 'Bina Mandiri' melalui dana yang mereka kumpulkan dari dana mandiri mereka hasil bekerja di luar negeri, yakni dana remitan. Para mantan pekerja migran ini kemudian mengembangkan usaha pengelolaan koperasinya tidak hanya sekedar simpan pinjam berpola grameen bank, namun juga mengembangkan berbagai Usaha Kecil Menengah (UKM) di antaranya: warnet, kerupuk pisang, pembibitan pohon sengon, dan empeng melinju.

Awal kelahiran UKM-UKM ini sebenarnya dari kesadaran mereka untuk mengembangkan dana remitan mereka yang sudah dikelola di koperasi 'Bina 
Mandiri' dengan pola grameen bank dalam pola simpan pinjamnya, sejak tahun 2010. Dengan bertambahnya dana dan keanggotaan koperasi tersebut, maka banyak saran dari masyarakat dan peneliti untuk mengembangkan dana tersebut untuk menciptakan peluang usaha bagi masyarakat dengan bentuk kewirausahaan, yang kemudian disepakati untuk menciptakan UKM.

Bahkan pada pertengahan tahun 2013 bekerjasama dengan salah satu perangkat lunak computer diberikan bantuan 10 seperangkat komputer, dengan menciptakan website usaha online bagi UKM-UKM yang direkomendasikan oleh Dinas Tenaga Kerja Kabupaten Malang dan Dinas Koperasi Kabupaten Malang.

Kesadaran ini sebenarnya tidak pernah lepas dari kondisi masyarakat dewasa ini terhadap arti pentingnya berkoperasi yang telah menjadi kebutuhan sebagian masyarakat, sebab hidup berkoperasi berarti membangun perekonomian secara bersama-sama. Hal ini dapat dibuktikan dengan makin pesatnya pertumbuhan koperasi dengan beraneka ragam jenisnya yang menunjukkan meningkatnya animo dan pengertian masyarakat akan peran koperasi di lingkungan mereka.

Koperasi merupakan wadah untuk mengembangkan potensi, peran dan pemberdayaan masyarakat baik di perkotaan maupun di pedesaan. Koperasi merupakan sokoguru perekonomian di Indonesia dan merupakan wadah untuk mengembangkan potensi, peran dan pemberdayaan masyarakat di pedesaan. Koperasi diharapkan mampu menangani berbagai masalah sosial dan ekonomi yang diarahkan pada pemerataan hasil pembangunan, pengembangan sumberdaya manusia yang berkualitas dan pemeliharaan lingkungan. Sebagian besar integral dari tata perekonomian nasional, koperasi memiliki kedudukan dan peran yang sangat strategis dalam menumbuhkembangkan potensi ekonomi rakyat. Oleh karena itu, koperasi secara bersama dan berdampingan dengan pelaku usaha lain harus mampu tumbuh menjadi badan usaha dan sekaligus sebagai gerakan dan penggalang ekonomi rakyat serta memiliki jaringan usaha dan daya saing yang tangguh guna mengantisipasi berbagai peluang dan tantangan pada masa yang akan datang (Muslimin, 2002).

Sampai saat ini masalah yang sering dihadapi oleh UMKM adalah masalah permodalan. Sebagian besar modal tersebut berasal dari modal sendiri. Perkembangan UMKM dari waktu ke waktu secara rutin harus dilakukan pengkajian, penyempurnaan dan peningkatan. Hal ini masalah yang dihadapi adalah kondisi pengusaha pada umumnya lemah dalam kredit modal kerja. Permasalahan modal tersebut timbul karena tidak adanya titik temu Usaha Mikro Kecil Menengah di Indonesia antara lain adalah masih belum menjalankan bisnisnya dengan prinsip-prinsip manajemen modern, tidak/belum memiliki badan usaha resmi, serta keterbatasan asset yang dimiliki. Sementara itu, di sisi kreditur, pemodal atau lembaga pembiayaan untuk melindungi resiko kredit menuntut adanya kegiatan bisnis yang dijalankan dengan prinsip-prinsip manajemen modern, izin usaha resmi serta adanya jaminan (collateral).

Lembaga perbankan menjadi salah satu sumber modal, secara optimal masih belum membantu permasalahan yang dihadapi usaha kecil menengah. Relatif tingginya tingkat bunga kredit perbankan, prosedur serta persyaratan pengajuan kredit yang relative sulit untuk dipenuhi, serta tidak adanya jaminan merupakan alasan utama bagi sebagian besar Usaha Mikro Kecil Menengah untuk tidak mengajukan kredit kepada perbankan, untuk usaha kecil menengah dengan segala keterbatasannya masih sulit untuk meraih modal dari sumber-sumber modal dan lembaga-lembaga keuangan nonbank.

Kurangnya pemahaman tentang koperasi sebagai badan usaha yang memiliki struktur kelembagaan (struktur organisasi, kekuasaan, dan insentif) yang unik dan khas dibandingkan badan usaha lainnya, serta kurang memasyarakatnya informasi tentang praktik-praktik berkoperasi yang benar (best practices), menimbulkan berbagai permasalahan mendasar yang menjadi kendala bagi kemajuan perkoperasian. 
Pertama, banyak koperasi yang terbentuk tanpa didasari adanya kebutuhan atau kepentingan ekonomi bersama dan prinsip kesukarelaan dari para anggotanya, sehingga kehilangan jati dirinya sebagai koperasi sejati yang otonom dan swadaya/mandiri.

Kedua, banyak koperasi yang tidak dikelola secara profesional menggunakan teknologi dan kaidah ekonomi modern sebagaimana layaknya sebuah badan usaha. Ketiga, masih terdapat kebijakan dan regulasi yang kurang mendukung kemajuan koperasi. Dan, keempat, koperasi masih sering dijadikan alat oleh segelintir orang/kelompok, baik di luar maupun di dalam gerakan koperasi itu sendiri, untuk mewujudkan kepentingan pribadi atau golongannya yang tidak sejalan, atau bahkan bertentangan dengan kepentingan anggota koperasi yang bersangkutan dan nilai-nilai luhur, serta prinsip-prinsip koperasi. Akibatnya, kinerja dan kontribusi koperasi dalam perekonomian relatif tertinggal dibandingkan badan usaha lainnya, dan citra koperasi di mata masyarakat menjadi kurang baik. Lebih lanjut, kondisi tersebut mengakibatkan terkikisnya kepercayaan, kepedulian dan dukungan masyarakat kepada koperasi.

Masalah Pengembangan UMKM di Kabupaten Malang atau Propinsi Jawa Timur secara luas masih dinilai belum mendapat perhatian yang cukup dari pemerintah, hal ini tercermin dari kebijakan pembangunan yang masih kurang memperhatikan kawasan Pengembangan UMKM dan lebih mengarah kepada wilayah-wilayah yang padat penduduk, aksesnya mudah dan potensial, sedangkan kebijakan pembangunan bagi daerah-daerah terpencil, terisolir dan tertinggal Paradigma pengelolaan kawasan Pengembangan UMKM di Jawa Timur di masa lampau sebagai "halaman belakang" wilayah NKRI membawa implikasi terhadap kondisi kawasan Pengembangan UMKM di Jawa Timur saat ini yang tersolir dan tertinggal dari sisi sosial dan ekonomi. Munculnya paradigma ini, disebabkan oleh sistem politik di masa lampau yang sentralistik dan sangat menekankan stabilitas keamanan. Di samping itu secara historis, hubungan Indonesia dengan beberapa negara tetangga pernah dilanda konflik, serta seringkali terjadinya pemberontakan-pemberontakan di dalam negeri.

Konsekuensinya, persepsi penanganan kawasan Pengembangan UMKM di Jawa Timur lebih didominasi pandangan untuk mengamankan Pengembangan UMKM di Jawa Timur dari potensi ancaman dari luar (external threat) dan cenderung memposisikan kawasan Pengembangan UMKM di Jawa Timur sebagai sabuk keamanan (security belt). Akibatnya pengelolaan kawasan Pengembangan UMKM di Jawa Timur dengan pendekatan kesejahteraan melalui optimalisasi potensi sumberdaya alam kurang mendapat perhatian, terutama dalam menggerakkan masyarakat atau UMKM untuk memaksimalkan penggunaan potensi daerah baik yang dilakukan pemerintah maupun swasta. Kehidupan masyarakat di kawasan Pengembangan UMKM di Jawa Timur dengan kondisi infrastruktur yang belum memadai dan kurang memiliki aksesibilitas yang baik, pada umumnya sangat dipengaruhi oleh kondisi sosial ekonomi di negara tetangga. Kawasan Pengembangan UMKM di Jawa Timur di Kalimantan dan Sulawesi Utara misalnya, kehidupan sosial ekonomi masyarakat pada umumnya berkiblat ke wilayah negara tetangga yang infrastrukturnya lebih baik. .Pengaruh sosial ekonomi yang lebih kuat dari wilayah negara tetangga berpotensi mengundang kerawanan di bidang politik.

Potensi sumberdaya alam yang berada di kawasan Pengembangan UMKM di Jawa Timur, baik di wilayah darat maupun laut cukup besar, namun sejauh ini upaya pengelolaannya belum dilakukan secara optimal. Potensi sumberdaya alam yang memungkinkan dikelola di sepanjang kawasan Pengembangan UMKM di Jawa Timur, antara lain sumber daya kehutanan, pertambangan, perkebunan, pariwisata, dan perikanan. Berdasarkan hasil survey yang telah dilakukan di Propinsi Jawa Timur terdapat beberapa permasalahan yang dihadapi masyarakat di kawasan Pengembangan UMKM di Jawa Timur 
dalam pengembangan potensi potensial daerah. Secara umum permasalahan yang dihadapi pada di Kabupaten Malang terutama daerah Malang Selatan yang berbatas dengan masih terkait dengan kemampuan SDM, modal kerja, penguasaan teknologi, sarana produksi dan tingkat pemanfaatan lahan.

Kabupaten Malang terutama Malang Selatan yang berada di Propinsi Jawa Timur memiliki potensi yang cukup besar, seperti pada sektor pertanian, sektor peternakan, dan sektor lain. Walaupun sektor tersebut berkembang seiring dengan pertumbuhan pembangunan, akan tetapi perkembangannya mengalami berbagai permasalahan yang cukup berarti. Setelah melakukan identifikasi, ditemukan 6 (enam) permasalahan pokok yang dihadapi dalam pengembangan potensi daerah yaitu : kemampuan SDM, modal kerja, penguasaan teknologi, sarana produksi, prasarana dan sarana penunjang dan tingkat pemanfaatan lahan.

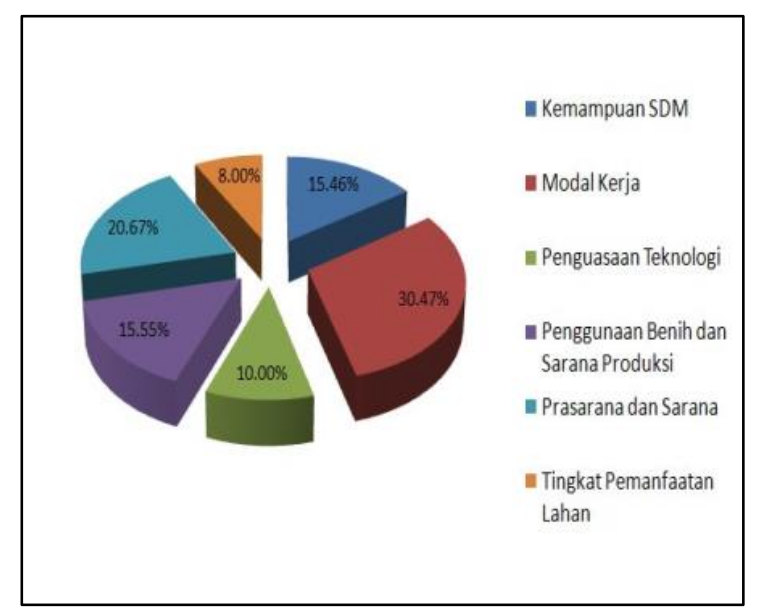

Gambar 1. Hasil Wawancara tentang Akumulasi Permasalahan Pengembangan Ekonomi di Lokasi Studi

Berdasarkan gambar di atas, permasalahan modal kerja merupakan masalah yang paling krusial menurut persepsi responden (30,47\%), diikuti sarana prasarana pendukung $(20.67 \%)$, penggunaan benih dan sarana produksi $(15,55 \%)$, kemampuan SDM $(15,46 \%)$, penguasaan teknologi (10\%) dan tingkat pemanfaatan lahan (8\%).

Sedangkan di Kabupaten Malang berdasarkan hasil depth interview serta
FGD yang dilakukan, permasalahan yang dihadapi masyarakat dalam pemanfaatan potensi daerah tidak jauh berbeda hanya tingkat kadar permasalahan yang intensitas yang tidak sama sebagaimana terlihat pada gambar berikut :

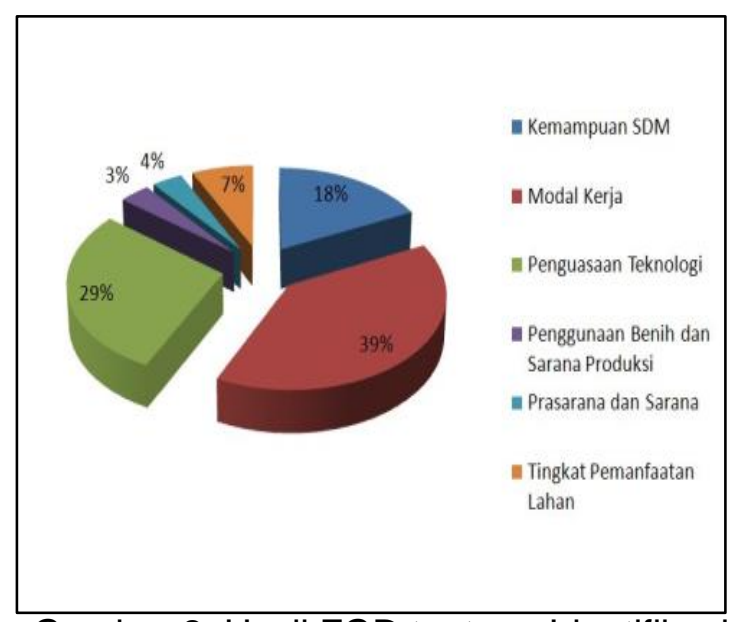

Gambar 2. Hasil FGD tentang Identifikasi Permasalahan Pengembangan Ekonomi di Lokasi Studi

Pada gambar di atas dapat dilihat bahwa permasalahan modal kerja di Kabupaten Malang masih merupakan masalah yang utama (39\%), selanjutnya diikuti penguasaan teknologi (29\%), kemampuan SDM (18\%), pemanfaatan lahan $(7 \%)$, prasarana sarana pendukung $(4 \%)$, dan tingkat pemanfaatan lahan $(3 \%)$.

\section{KESIMPULAN}

Kesimpulan yang dapat diambil dalam penelitian ini, adalah :

1. Kebersamaan dan rasa keluargaan merupakan pererat utama lahirnya koperasi 'Bina Mandiri' yang didirikan oleh para purna TKW Korea Selatan, di Desa Kedungsalam Kecamatan Donomulyo Kabupaten Malang.

2. Koperasi lahir dari dana remitan yang dikumpulkan untuk proses penguatan pemanfaatan hasil kerja ke luar negeri.

3. Koperasi ini berdiri awalnya untuk membantu para keluarga TKW yang ditinggalkannya untuk menyediakan dana pinjaman jika mereka membutuhkan dana pinjaman secara mendadak

4. Koperasi ini berbentuk simpan pinjam yang dibentuk oleh para purna TKW dan diikuti oleh TKW-TKW di Korea Selatan dengan dana remitan. 
5. Dari simpan pinjam koperasi 'Bina Mandiri' inilah maka banyak para keluarga TKW yang memiliki kemandirian untuk berwirausaha dengan membuka UKM-UKM baru, seperti keripik pisang, emping melindu, warnet, dan lain sebagainya, meskipun masih terbatas dalam bentuk dana dan pengelolaannya (SDM), termasuk pemasarannya.

Berdasarkan hasil penelitian, dapat direkomendasikan beberapa hal, yaitu:

- Pemerintah terkait seperti Dinas Koperasi dan UKM, Dinas Transmigrasi, dan Dinas Pemberdayaan Perempuan dan BKKBN untuk lebih memperhatikan mereka, terutama dalam penguatan sumber daya manusia (SDM) masyarakat Kedungsalam Donomulyo Kabupaten Malang.

- Perlunya penggalian-penggalian potensi sumber daya alam (SDA) yang ada di Desa Kedungsalam Donomulyo Malang untuk memperkuat potensi ekonomi masyarakat, terutama produk UMKM.

- Perlunya pihak pemerintah dan swasta untuk membantu memperkuat SDM dan SDA Desa Kedungsalam Donomulyo Kabupaten Malang.

- Perlunya pihak pemerintah dan swasta membantu memperkuat koperasi simpan pinjam 'Bina Mandiri' dengan mengucurkan bantuan, baik berbentuk dana, alat koperasi, dan lain sebagainya.

- Perlunya pihak pemerintah dan swasta membantu memperkuat lahirnya UMKM-UMKM dari koperasi 'Bina Mandiri' dengan membantu memasarkan dan memperkuat potensi SDM yang ada

\section{DAFTAR PUSTAKA}

Blakely, E. J. 1994. Planning Local Economic Development: Theory and Practice. Sage Publications, USA.

Hilmy. U. 2008. Akses Dan Kontrol Pada Penghasilan Dalam Proses Bermigrasi (Studi di Desa Kedungsalam Kecamatan Donomulyo Kabupaten Malang)". Laporan Penelitian Solidaritas Perempuan: Dian Mutiara Crisis Centre.

Kuncoro. M. Grameen Bank \& Lembaga Keuangan Mikro dalam Kedaulatan Rakyat. Tersedia on-line http://www.kr.co.id. Diakses tanggal 2 Agustus 2018.

IFAD. 2000. Mengembangkan Sistem Keuangan Pedesaan untuk Masyarakat Miskin: Kerangka Perencanaan Untuk Tantangan, Kesempatan dan Pilihan. www. Humanitarianinfo.Org/...Livelihood /Docs/doc/ifadmicrofinancedevelopmen tpolicydocument-bahasa-220306.pdf

Manurung, V.T. 1998. Keragaan Kelembagaan Perkreditan Usaha Penangkapan Ikan Tuna Skala Kecil di Kawasan Indonesia Timur. FAE Vol. 16 No. 2.

Rahayu. D. 2007. Trafficking Buruh Migran, Qithos Digital Press: Sidoarjo.

Syafa'at. 2002. Menggagas Kebijakan Pro TKI: Model kebijakan perlindungan TKI ke Luar Negeri di Kabupaten Blitar. Lappera Pustaka Utama. Jogjakarta.

Sunyigono, A.K. 2006. Model Penguatan Ekonomi Masyarakat di Sekitar Bendungan Nipah Kabupaten Sampang. Penelitian Hibah Bersaing. Fakultas Pertanian. Universitas Trunojoyo Madura. 
2 Jurnal Pamator 